\title{
Correct Handwashing Education According to WHO Guidelines at MI Muhammadiyah Needs Magelang District
}

\author{
Ika Afifah Nugraheni*, Hapsari Wahyuningsih \\ University of 'Aisyiyah Yogyakarta \\ * Corresponding Email: ikaafifah@unisayogya.ac.id
}

\begin{abstract}
At the beginning of 2020, the world was shocked by the emergence of a new disease outbreak, Covid-19, which was caused by the SARS COV-2 virus. The school environment is one of the places that is vulnerable to the spread of this virus. An effective preventive measure against the spread of Covid-19 is the application of clean and healthy living habits (PHBS) in the school environment, one of which is the habit of washing hands. However, not all residents in the school understand how to wash their hands properly. The purpose of this service activity is to provide education about proper hands washing according to WHO for MI Muhammadiyah Need in Magelang Regency. The material needed for the implementation of the activity is a hand sanitizer liquid made from $70 \%$ active alcohol as a hand disinfectant. Implementation of community service activities using demonstration methods and hands-on practice of hands washing according to WHO. Based on this service activity, not all members of the MI Muhammadiyah Need was known the steps for hands washing properly according to WHO. Through this service, school residents are given knowledge and practice the 8 steps of hand washing according to WHO using a handsanitizer. Thus, school residents are expected to be able to apply proper hand washing methods in their daily life and socialize it to other individuals school residents are given knowledge and practice the 8 steps of hand washing according to WHO using a handsanitizer. Thus, school residents are expected to be able to apply proper hand washing methods in their daily life and socialize it to other individuals school residents are given knowledge and practice the 8 steps of hand washing according to WHO using a handsanitizer. Thus, school residents are expected to be able to apply proper hand washing methods in their daily life and socialize it to other individuals
\end{abstract}

Keywords: Covid-19, PHBS, hands washing, WHO

\section{INTRODUCTION}

On December 31, 2019, the world was shocked by the emergence of a new disease of unknown cause and origin. The case first appeared in Wuhan City, Hubei Province, China. On February 11, 2020, WHO designated this disease as Covid-19, which is caused by the SARS COV2 virus. This disease is spreading rapidly to all countries in the world. On March 11, 2020, WHO declared Covid-19 a world pandemic(Ministry of Health of the Republic of Indonesia, 2020).

Indonesia is one of the countries affected by Covid-19. The spread of the Covid-19 disease has reached all provinces in Indonesia, with positive cases and increasing deaths. This certainly has an impact on all areas of life, such as the economic, social, political, cultural, and security fields(Ministry of Health of the Republic of Indonesia, 2020). Until now, there is no effective treatment for this disease. The vaccine candidate for Covid-19 is still in the clinical testing stage. Preventive efforts that can be taken by the community against the spread of Covid-19 include the application of clean and healthy living behavior (PHBS).

Every individual has a big role to play in breaking the chain of the spread of Covid-19. Given the mode of transmission through droplets or physical contact between individuals, the transmission of Covid-19 can occur in all places, whether at home, travelling, workplaces, places of worship, tourist attractions or at schools. Schools are one of the most vulnerable places for the spread of COVID-19. The implementation of PHBS in schools means empowering students, teachers and the community to practice a clean and healthy lifestyle in the school environment. One of the indicators in PHBS is proper hand washing(Ministry of Social Affairs, 2020).

Hand washing is an important factor in preventing the spread of Covid-19. Hand washing activities properly and regularly are also effective in preventing the spread of various pathogenic 
microbes. Washing hands properly can stop the spread of viruses and other pathogens that are transmitted through direct or indirect contact, droplets, air and also through various objects around them. The pattern of spread of viruses and other pathogens can occur through several stages: 1) being on the hands and skin surfaces of individuals, or sticking to objects around them, 2) spreading due to physical contact between individuals, 3) viruses and pathogens being able to survive live on the surface of the skin and surrounding objects for a certain period of time, 4) improper hand washing, 5) contact with surrounding objects that have been contaminated with viruses and pathogens(WHO, 2009). At this point, improper hand washing can be a way for the spread of Covid-19.

Hand washing materials can use water and soap, as well as disinfectant liquids that have antiseptic abilities such as alcohol, chlorhexidine gluconate, chlorine derivative compounds, iodine, chloroxylenol, and triclosan. Antiseptic liquid made from $60-80 \%$ alcohol is effective at inhibiting viruses and other pathogens. In addition, alcohol antiseptic liquid is also safe when used as a daily disinfectant(WHO, 2009).

WHO has issued guidelines on proper hand washing. There are 8 steps to wash your hands using a hand sanitizer/handrub, with a duration of about 20-30 minutes to wash your hands. Hand washing is carried out before and after activities, after exposure to our body fluids and other people, after making contact with other people, or after touching objects around us.(WHO, 2009).

There are several reasons why MI Muhammadiyah needs to be the location of community service. The reasons for choosing this location include access to MI Muhammadiyah, which is far from the highway. This situation makes school residents less access to information about Covid19 and its prevention efforts. Through this service activity, MI Muhammadiyah Need school residents are expected to gain knowledge of Covid-19 prevention measures that can be carried out in schools. One of these prevention efforts is educating school residents about how to wash hands properly according to WHO guidelines. Thus, school residents can apply and socialize how to wash hands properly to other individuals and the surrounding community.

\section{MATERIALS AND METHODS}

The material used in the implementation of community service activities at $\mathrm{Ml}$ Muhammadiyah Need is a $70 \%$ alcohol-based disinfectant liquid. In addition, participants were distributed posters on how to wash hands properly according to WHO guidelines. The series of activities consists of 4 stages, namely 1) licensing for the implementation of activities, 2) consolidation of activities, 3) preparation of activities, and 4) implementation of service activities.

Licensing activities in this case relates to the willingness of partners, namely $\mathrm{MI}$ Muhammadiyah Need, to be used as a place for implementing science and technology for community service regarding PHBS education for school residents. Licensing is carried out by the implementing team through the School Principal. The next activity is consolidation to strengthen cooperation partner relationships that have been realized through licensing. In this activity, communication was carried out with the Principal of MI Muhammadiyah Need to discuss plans for implementing community service activities.

The preparation stage contains the preparation of materials and materials for the implementation of community service activities. The last stage is the implementation of activities at MI Muhammadiyah Need. The method used in the implementation of the service is demonstration and direct practice from service participants, while still implementing health protocols during the activity.

\section{RESULTS AND DISCUSSION}

Participants who took part in the implementation of community service activities were 13 people, consisting of 7 people from the MI Muhammadiyah Need and 6 people from the service implementation team. The activity will be held on Monday, August 10, 2020 at 09.00-10.30 WIB. The activity was carried out offline, located at MI Muhammadiyah Need while still paying attention to the Covid-19 health protocol. All activities are carried out within 1.5 hours. Due to the current 
situation during the Covid-19 pandemic, participants from the MI Muhammadiyah Need were only represented by the Principal, several teacher representatives and the Chair of the School Committee. Participants from students were not included during service activities because MI Muhammadiyah Need students were carrying out learning from home (BDR) activities.

The service team provided counseling on how to wash hands properly according to WHO guidelines. This is based on the fact that not all teachers and students understand the steps for washing hands properly. They think that hand washing is just washing hands with hand sanitizer or soap and water. In fact, between the fingers that are usually not reached by hand sanitizer or soap can be a hiding place for microbes and viruses. Hand washing has become less effective in protecting the body from various diseases, including Covid-19. Therefore, school residents need to be given an understanding and education about how to wash their hands properly, so that the handwashing movement is truly effective as a preventive effort against the spread of Covid- 19 .

The speakers at the handwashing socialization activity were students from the Biotechnology Study Program. The involvement of students in community service activities is not only operational, but students are trained to become speakers who are tasked with conveying information and knowledge to the community. Nevertheless, the lecturers who implement the service continue to monitor, guide and assist during the implementation of the counseling.

You can wash your hands using a hand sanitizer or soap and water. Both have the same effectiveness to inhibit the growth of microbes and viruses. In this counseling session, service participants were distributed posters on how to wash their hands properly. Participants learn by looking at the posters, as well as seeing first hand demonstrations on how to wash hands properly, which is practiced by students. This educational activity on how to wash hands is not only in the form of visual writings and poster images, but also through demonstrations, so that participants really understand the steps for proper hand washing.

According to $\mathrm{WHO}$, there are 8 steps to washing hands properly. At this stage the disinfection media uses a hand sanitizer containing $70 \%$ alcohol. The steps for washing hands using a hand sanitizer are as follows:

a. Spray enough hand sanitizer in the palm of the hand.

b. Rub the palms in a circular motion.

c. Alternately rubbing the back of the hand, for the right and left hands.

d. Rub each other between the fingers.

e. Rubbing the nails and fingers so that the hands are locked and cupped together, as well as circular motions or rubbing each other.

f. Rub the thumb of the left hand with the right hand, and do it alternately between the right and left thumbs.

g. Rub the fingertips of the right hand on the palm of the left hand in a circular motion, and do it alternately.

h. The hand sanitizer is allowed to dry on the hands by itself, no need to wipe it with a towel or tissue.

Furthermore, the service participants directly practiced how to wash their hands based on the results of the demonstration from the service team. Thus, participants can understand and remember each step of hand washing correctly. From this stage, the team also monitored the level of understanding of the service participants regarding the correct way of washing hands.

Based on the observations, the service participants did not all have the understanding and knowledge of how to wash their hands properly. Participants' understanding of hand washing was still simply washing the palms with a hand sanitizer. How to wash hands properly according to WHO is still a new thing for participants. When directly practicing the correct way of washing hands, participants still need help from the implementation team to provide examples and guidance. From the implementation of this activity, service participants are expected to continue practicing how to wash their hands properly and socialize it to MI Muhammadiyah Need students, 
their families and the surrounding community. Thus, preventive efforts to prevent the spread of Covid-19 can work effectively.

\section{CONCLUSIONS AND SUGGESTIONS}

The conclusion from this community service activity is that not all people know how to wash their hands properly according to WHO guidelines. There are 8 steps to wash your hands using a hand sanitizer that is explained by WHO. Each of these steps was demonstrated by the service team and practiced directly by the participants. School residents participating in the service from MI Muhammadiyah need to become more aware and understand the stages of proper hand washing as one of the implementations of PHBS in order to prevent the spread of Covid-19 in the school environment. Suggestions for the future for this activity are that it is also necessary to educate the public about the importance of using masks during the Covid-19 pandemic. This is because the use of masks in schools and the surrounding community is still low. In fact, masks are also a primary effort in preventing Covid-19.

\section{ACKNOWLEDGMENTS}

Community service activities were carried out well because of the help and cooperation of various parties. The implementation team would like to thank: 1) Asiyiyah University Yogyakarta, 2) LPPM Aisyiyah University Yogyakarta as a provider of internal grants for competition service,

3) Muhammadiyah $\mathrm{Ml}$ is needed as a location for service implementation.

\section{REFERENCES}

Ministry of Health of the Republic of Indonesia. (2020). Guidelines for Preparedness for Coronavirus Disease (COVID-19). In Directorate General of Disease Prevention and Control (pp. 1-88).

Ministry of Social Affairs. (2020). Clean and healthy living behavior (PHBS) strengthens the capabilities of children and families.

WHO. (2009). on Hand Hygiene in Health Care: a Summary First Global Patient Safety Challenge Clean Care is Safer Care (pp. 1-64). 